\title{
Shifting styles of church leadership: Paul's pragmatic leadership style in 1 and 2 Corinthians during the organization of the collection for Jerusalem
}

\author{
S J Joubert ${ }^{1}$ \\ (University of Pretoria)
}

\begin{abstract}
Shifting styles of church leadership: Paul's pragmatic leadership style in 1 and 2 Corinthians during the organization of the collection for Jerusalem

This essay focuses on Paul's shifting leadership styles in his relationship with the church in Corinth during the organization of an ecumenical collection for the believers in Jerusalem (cf 1 Cor 16:1-4; 2 Cor 8-9). Paul's basic textual strategy in 2 Corinthians 8-9, which involves the assignment of new roles to the interlocutors, serves to anti-structurally bridge the hierarchical gap between him (as the mild patriarchal figure) and the Corinthians (as his spiritually mature children) within the intratextual discourse. This pragmatic adjustment of the apostle's autocratic leadership role in 1 Corinthians 16, in order to salvage the collection project in Corinth, serves as an example to modern church leaders to take cognizance of the impact of social and ideological contexts on their own styles of leadership.
\end{abstract}

\section{INTRODUCTION}

The issue of church leadership has been a topic of serious debate in theological circles during the past few years. Rightly so, because we live in a dynamic post-modern world where the church cannot afford the luxury of outdated leadership styles that facilitate the necessary changes in society in general and the church in particular. In this regard, the apostle Paul serves as an excellent example of a pragmatic leader. He did not hesitate to adjust his own style of leadership whenever the situation demanded such actions of him. In this essay we shall briefly focus on the apostle's shifting leadership styles in his relationship with the church in Corinth during his organization of an ecumenical collection for the believers in Jerusalem (1 Cor 16:1-4; 2 Cor 8-9).

\footnotetext{
1 Professor S Joubert is a research fellow of the Department of New Testament of the University of Pretoria.
} 


\section{CORINTHIANS 16:1-4: PAUL, THE AUTOCRATIC LEADER}

In verse 1, Paul responds in an authoritarian manner to a question from the Corinthians regarding the collection that they were organizing for the impoverished believers in Jerusalem. His intratextual rhetoric in 1 Corinthians 16 (cf e.g. the imperatives $\pi \circ\left\llcorner\eta \sigma \alpha \tau \epsilon-\mathrm{v} 1\right.$, and $\tau \iota \theta^{\prime} \epsilon \tau \omega-\mathrm{v} 2$ ) actually serves to stress his own apostolic authority as broker of the heavenly patrons, while at the same time also emphasising the hierarchical distance between him and the Corinthian believers. Since Paul believed himself to be under the direct control of God's Spirit (1 Cor 7:40), he presents himself in 1 Corinthians 16 as being endowed with the divinely assigned authority to head the organization of the collection. As the inferior party within this relationship, the only legitimate option open to the Corinthians is to obediently follow his instructions. But Paul's apostolic authority is not merely limited to his supervision over the Corinthians. The Galatian believers also fall under his jurisdiction, as he indicates in verse 1 . And their obedience to his instructions led to the successful completion of their collection effort for Jerusalem. Therefore, the Corinthians now also have to imitate the Galatians' exemplary behaviour. Paul makes it clear that his directions in verses 2-4 are an exact duplication of his instructions to the Galatians. These instructions thus serve as the blueprint for any successful collection.

To emphasise the necessity of a large contribution from the Corinthians, Paul states in verse 4 that he will only accompany the Corinthian delegation to Jerusalem if their gift is worthy of it (Orr \& Walther 1987: 356f; Wolff 1996:430; Thiselton 2000). As the divinely appointed apostle, who is responsible for the proclamation of the good news throughout the Graeco-Roman world, Paul implies that his itinerary is already set (5ff.). He cannot occupy himself with trivialities, such as an inferior collection, that will not serve its basic purpose, namely, to effectively address the needs of the poor in the Jerusalem church. Therefore, he alludes to a personal inspection of the Corinthian collection upon his arrival before committing himself to travel to Jerusalem. If he eventually decided to go to Jerusalem, the Corinthian delegates may then accompany him, not vice-versa.

Paul's authority in 1 Corinthians 16:1-4 is underscored further by his remark that he will issue letters of recommendation to each member of the Corinthian delegation to ensure that they would be shown the necessary hospitality by fellow believers en route to Jerusalem, and that they would also be received in a friendly manner by the Jerusalem community. Letters of recommendation within the Graeco-Roman world usually granted messengers the same authority as that of their senders (Klauck 1998:75-79). Since they thus 're-presented' their senders, they 
could only act within the mandate endorsed by the former. In this regard the Corinthian delegates were to be sent out under Paul's name to deliver the collection. They would be entrusted with his apostolic authority, as his signature on the letters of recommendation would have indicated to all the churches along the way, as well as to the Jerusalem church.

On the basis of the asymmetric distribution of power, which Paul perceived to exist between himself and his communities, he claimed the right to exercise influence over the formulation and reproduction of the symbolic orders that defined and shaped the nature and identity of the collection. In Corinth it implied following an autocratic strategy. The reason was simple: this strategy worked in the Galatian churches. Their successful collection effort was a testimony to the effectiveness of Paul's control over the collection process in terms of:

- The setting of goals: Paul's goal was to address Jerusalem's poverty. In order to attain this goal, he set clear goals for the Galatians and the Corinthians. This included the completion of their collection efforts within specific time frames through putting money one side on Sundays. The appointment of local delegates to escort the collection to Jerusalem (16:2-3) also formed part of these goals.

- The monitoring and evaluation of the various stages of the collection: the second phase of the Corinthian collection effort involved Paul's personal presence. He had to determine whether the believers had followed his instructions, and whether they had put together enough money in order to justify his accompanying the collection to its final destination.

\section{THE CRISIS IN CORINTH BETWEEN 1 CORINTHIANS 16 AND 2 CORINTHIANS 1-9}

Paul's general style and role, as well as the role conferred upon the readers in 2 Corinthians 89 , differ noticeably from that of 1 Corinthians 16:1-4. Instead of the autocratic style of 1 Corinthians 16, very few explicit commands concerning the collection are to be found in 2 Corinthians 8-9. Paul rather limits himself to some advisory remarks, while, at the same time, emphasising the spiritual maturity and positive attributes of the Corinthians. Over against the hierarchical distance between himself and the Corinthians in 1 Corinthians 16, Paul in 2 Corinthians 8-9 bridges the distance between them by, in anti-structural fashion, adopting a very mild patriarchal role. Since the collection project in Corinth came to an abrupt halt because of the disturbed relations between the apostle and the believers after the delivery of 1 
Corinthians, Paul had to drastically change his strategies in order to ensure the completion of the collection.

In view of the available information in 2 Corinthians 19, we may briefly construct the following scenario for the situation between the writing of 1 Corinthians and 2 Corinthians 1-9 (Klauck 1986:5-7): Shortly after the dispatching of 1 Corinthians, people preaching a different gospel infiltrated the Corinthian community. When hearing of this, probably from Titus after he returned from Corinth for his first visit to organise the collection (2 Cor 8:6), Paul changed his itinerary (Barnett 1997:387). He undertook an unannounced visit to Corinth (cf 2 Cor $12: 14 ; 13: 1)$. Unfortunately, this led to a confrontation with a prominent member of the community who apparently sided with the intruders in their strong criticism of Paul's apostolic ministry. After this conflict (cf 2 Cor $2: 5 ; 7,12)$ the apostle hastily departed, deeply humiliated. He then wrote a letter from Ephesus ( $\mathrm{cf} 2$ Cor $2: 4 ; 7: 8$ ) “...den wir aufgrund von 2,4 den Tränebrief nennen (see 7:8) und der eine scharfe Abrechnung mit allen Kräften in der Gemeinde enthalten hat, die sich gegen Paulus stellten und an seiner Autorität zweifelten" (Klauck 1986:6). Fortunately for Paul, the response from the Corinthians to this letter was positive. He heard this good news when he eventually met with Titus in Macedonia (2 Cor 2:12ff). The latter returned from Corinth with information that the person who had earlier challenged Paul's honour in public had been reprimanded by a meeting of the entire community (2 Cor 2:6). In response, Paul soon afterwards wrote a "Letter of Reconciliation", which was also delivered by Titus.

\section{CORINTHIANS 8-9: PAUL AS FATHER-FIGURE}

\subsection{Introduction}

Paul finds himself in an argumentative situation anew in 2 Corinthians 8-9. Although the "Letter of Tears" succeeded in eliciting the desired response from the Corinthians, their collection project was still on hold. Paul is therefore faced with the challenge of "moving" the Corinthians once again from one ideological position to another in 2 Corinthians 8 and 9 , that is, from their refusal to complete the collection to renewed participation therein.

In the praescriptio of 1 and 2 Corinthians, Paul presents himself as an apostle of Christ, whereas the Corinthians are addressed as ekklesia, churh of God (1 Cor 1:1-2; 2 Cor 1:1). In his role as apostle Paul clearly commands the centre stage. As the normative broker of the secrets of God (1 Cor 2:1), he possesses the necessary authority to demand total obedience to his instructions from the Corinthians (1 Cor 7:8; 16:1-4). Although Paul does make use of his apostolic authority, he frequently 
alternates this role in the course of the Corinthian correspondence by, at times explicitly, but more often implicitly, presenting himself in an intimate way as a typical "father-figure" towards the Corinthians as his "children" (e.g., 1 Cor 4:14-15; 2 Cor 6:13; 12:14-16 - cf Meeks 1983:29-58; Peterman 1997:172-174). Especially in 2 Corinthians, Paul often instructs the Corinthians as his 'children': he admonishes them (2 Cor 2:8); regulates their conduct (2 Cor 13:11); expects of them to imitate his behaviour, and be obedient to him (1 Cor 3:1-2; 2 Cor 2:9). At the same time, Paul, as the "loyal father", states that he is not only saving up an "inheritance" for them (2 Cor 12:14), but that he is even prepared to sacrifice his own life for them (2 Cor 12:15). He is also cheered by their good deeds ( 2 Cor 7:16), and constantly prays for them (2 Cor 13:9). This patriarchal role serves as an important intra-textual proof of Paul's goodwill towards the Corinthians, while, at the same time, reflecting on his own integrity and credibility. Paul's emphasis on his fatherly integrity in 2 Corinthians $1-9$ is supported further by his repeated recollection of his own virtues, persecution, suffering, hard work, and selfless care for his communities (2 Cor 6:4ff.; 11:8ff.).

In his role as patriarchal figure, Paul still holds the leading position in the discourse. The role conferred upon the readers in this regard is one of obedience, but also of child-like trust in him. By adopting this role, Paul does, however, in anti-structural fashion, break through the strict hierarchical relationship that should actually exist between him and the Corinthians. At the same time, this father-child relationship places much (implicit) pressure on the intended readers to conform to their father's wishes. According to Holmberg (1978:79):

"...we find in all letters, except Romans, the conception of apostolic fatherhood and imitation, which, as a description of the relation between the apostle and the local church is milder and at the same time more demanding than a list of rights and obligations. It is milder because it signifies an affectionate relation, but it is also more demanding - when are you free from the obligation of respecting and obeying 'father', and when have you repaid the debt of gratitude to the person who has given you life (eternal)?"

As part of Paul's textual strategy in 2 Corinthians 8-9, he does not emphasise the hierarchical distance between himself and the Corinthians, as is the case in 1 Corinthians 16,1-4. Both the "autocratic apostle figure" of 1 Corinthians 16, who could assert himself as being in a position to give direct orders and exercise complete control over all aspects of the collection, and the "immature believers", who were ignorant as to the 
correct behaviour regarding to the collection, are now replaced by "new" intra-textual personages.

In 2 Corinthians 89 Paul acts as a mild father figure, who, on the surface structure of the text, only offers advise to his "mature children" that experience spiritual abundance (8:7). Instead of issuing commands, or unilaterally taking charge of the organisation of the collection, Paul now rather opts to teach by way of example ( $\mathrm{cf}$ the references to the behaviour of the Macedonians [8:1-5] and that of Christ [8:9]). At the same time, he also emphasises his abundant love for them (8:8); offers his advice to them in their own interest $(8: 10)$; is concerned about their socio-economic position (8:13); and boasts to others about them (8:24; 9:2-3). In 2 Corinthians 9 Paul follows an even more informal style than in chapter 8. He switches from the first person plural to singular in references to himself. This implies that he, within the progression in the intra-textual discourse, supposes a positive change of attitude on the part of his readers regarding himself and the collection.

\subsection{The potestas of the paterfamilias}

In order to understand more fully the meanings inherent in this "fatherchild" relationship between Paul and the Corinthians, we need to briefly focus on the typical role-expectations, responsibilities and functions of Roman fathers and children from about the first century. Clearly, Paul, the pragmatic leader, not only adjusted his leadership role after the conflict with the Corinthians, but also took note of his social environment when adapting a milder, patriarchal role in the interaction with the Corinthians.

The paterfamilias, the oldest surviving male ascendant, formally headed the Roman familia. All members of the familia were subjected to his lifelong authority or potestas, unless, of course, he terminated it himself for instance by the adoption of a filius into another family, or by emancipatio (Dixon 1992:40). This potestas, which was legally recognised and protected, provided the paterfamilias with the right of life and death over his descendants. He had the power to decide whether a newborn child was to be allowed into the family, or exposed to die. At the same time, the paterfamilias possessed formal ownership over all property possessed by his familia. He could legitimately disown or expel his sons from their domus, and even sell them off as slaves or have them imprisoned. Furthermore, the head of the household had considerable influence over the marriage of his offspring. Not only did his sons and daughters need his consent to get married, but the law also gave him enough leverage to force them into marriages against their will. At the same time, he could also unilaterally dissolve his children's marriages by imposing a divorce (cf also Treggiari 1991:459ff). 
Patria potestas formed the backbone of Roman society (Schulz 1992:142). However, the available literary evidence does not support the notion of peculiarly, oppressive or violent father-son relationships in the Roman world. Invocation of the father's vitae necisque potestas against his sons, or exheredatio (disinheritance) was not daily occurrences. At the same time corporeal punishment was also not accepted everywhere, as the likes of Plutarch, Seneca and Horace make clear. Whipping of children was actually eschewed by them because it could inculcate a servile mentality by treating children in a contemptible way.

Patria potestas should be understood in terms of the power invested in the father as head of the familia. Roman law protected his power, although patresfamiliarum very seldom used their powers to their fullest extent. It was expected of children to wholeheartedly submit themselves to the potestas of their fathers, since filial obedience brought honour and public esteem to the position of the paterfamilias in the eyes of others. It pointed to the fact that he was able to discipline and control his family.

\subsection{Pietas in the family}

Pietas, when related to relations within the family, reflects the reciprocal obligations and the affectionate devotion of fathers and children to each other. "Parents were obliged to look after the best interests of their children, just as children were obliged to respect and protect their parents" (Saller 1994:112f). The ideal of pietas was frequently stressed as the basis of patria potestas. It was impressed on Roman fathers not to abuse their powers by maltreating their families. Dixon (1987:99-113) identifies a so-called "sentimental idea of the family" that flourished from the time of the late Republic onwards, where the ideal of concordia between husband and wife was frequently emphasised, as well as the extension of affection to children. Philosophers such as Cicero, Seneca and Plutarch encouraged fathers to love their children even more than their own wealth and honour, to be proud of them, to take special interest in their studies, to cherish high ambitions for them, to care about their physical and moral well-being, and to be concerned about their future marriages (Joubert 1995:215).

\subsection{Reciprocity between parents and children}

According to the well-known philosopher, Dio Chrysostom (Oratio 75.6), the relationship between children and parents was one of the most important reciprocal relationships. Greek and Roman writers alike confirm this view (Stevenson 1992:421ff). Xenophon (Mem II, 2:1-13), for instance, refers to the discussion between Socrates and his son 
Lamprocles, where the latter is reminded at length of his debts towards his parents for his birth, rearing and education. Cicero (De off 1:58), in turn, states that a man's responsibility works both ways, to parents and children, but the greater obligation would be to his parents: "...country would come first, and parents, for their services have laid us under the heaviest obligation; next come children and the whole family, who look to us for support and can have no other protection".

Ancient writers are convinced that parental benefactions are based upon their love for their children, but also on the expectation of future recompense. In return for the gift of life, education, and security, children must show respect to their parents, be obedient to them, and also care for them in their old age. These responsibilities actually had to continue until after the death of the parents, since it was also the responsibility of children to ensure a decent burial for them.

\subsection{Metaphorical use of familial terms}

The father metaphor played a significant role in Roman life. For instance, the title parens patriae was offered to Cicero by the Princeps Senatus after saving the Republic from Cataline's conspiracy. Caesar was also conferred the title pater patriae in 45 or $44 \mathrm{BCE}$, while Augustus officially received the same title in 2 BCE. With the reign of Augustus a so-called "patriarchal religion" took shape in the Empire 2 . After becoming pontifex maximus in $12 \mathrm{CE}$, and after identifying family gods with that of the state, the imperial ruler became an image of divine rule. Zeus was now regarded as the paternal guardian of the state. His rule as father of the gods and mankind provided the analogy for the "patriarchal" reign of the emperors. Stevenson (1992:424) points out that both the Greeks and the Romans also developed a concept of the ideal benefactor, and frequently used the father analogy to designate such figures. During the first two centuries of the Christian era, this ideal benefactor-beneficiary relationship seems to have been applied particularly to relationships involving the Roman emperor ${ }^{3}$. At the same time, the state was also referred to as "fatherland" (patria), its produce sustained life, it united people as in a family, it provided shelter and the fatherland, its laws regulated the lives of all its "children", etcetera.

\footnotetext{
2 Augustus was soon pictured as saviour and the new founder of Rome. Since Romulus was the first to be called the father of Rome, it made political sense to link the figures of Romulus and Augustus. The latter probably functioned as the physical embodiment of the lost ideals of Romulus in his role as pater patriae, (that is, the universal patron) of the populus Romanus.

3 From the time of Homer the (potential or actual) benefactor was actually framed in procreative/tuletary terms; that is, the power to give, sustain and protect life.
} 


\section{CONCLUSIONS}

Firstly, Paul's use of patriarchal language should be understood within the framework of the altered relationship between him and the Corinthians after their collection attempt came to a halt. In order to prepare them once more for a favourable disposition towards the collection, and to elicit their adherence, Paul creates a new intra-textual rhetorical situation in 2 Corinthians 8-9. This strategy involves the adaptation of new roles by the interlocutors, as well as a new textual strategy. In order to bridge the hierarchical and ideological distance between himself and the Corinthians, Paul opts for a mild patriarchal role, while portraying his readers as mature children who now only need his fatherly advice.

Secondly, Paul's use of patriarchal language should also be understood against the framework of the family, the primary social institution in the ancient Mediterranean world. According to Roman people's common-sense knowledge, the paterfamilias possessed lifelong potestas over all his children. Obedience to his authority was, therefore, expected of all members of his familia. In spite of the theoretically extreme powers vested in the paterfamilias, this was tempered by the principle of pietas, the dutiful affection of fathers and children towards each other. According to the generally accepted view, parental benefits placed children in permanent debt to them. As part of the repayment of their debt of gratitude, it was expected of children to show respect to their parents and take care of them in their old age. At the same time, patriarchal imagery was also used metaphorically to give expression to and legitimise existing political realities, such as the reign of the gods and the emperor. Patriarchal language also provided a handy "vehicle" to depict the image of the ideal benefactor in the Graeco-Roman world ( $\mathrm{cf}$ Van der Watt 2000).

The metaphorical application of family language by Paul in 2 Corinthians 8-9 anti-structurally bridges the hierarchical gap between him and the Corinthians within the intra-textual discourse. Over against Paul's apostolic role, which reflects his position as mediator/broker of the heavenly patrons, his patriarchal role is related to his position in terms of the believers under his supervision. In other words, Paul's apostolic role symbolises his claim to authority as the officially assigned representative of God, while his patriarchal role points to his position as the head of his churches as a new, fictive, family.

Paul's patriarchal role does not diminish his authority in any way. In this role he only acts less strictly than what his apostolic role demands. But within this familial relationship the implicit pressure on the Corinthians is probably much greater to adhere to Paul's fatherly "advice" than within an explicit authoritarian situation such as 1 Corinthians 16, 1-4. Within the framework of the ancient Mediterranean 
family, the responsibilities of children were clearly demarcated: they had to show lifelong obedience to their paterfamilias. Disobedience signalled disrespect, and posed a serious threat to their position within the familia. At the same time, due to the asymmetric nature of the reciprocal relationship between children and their parents, the former remained permanently indebted to them. Since all these stereotyped meanings are invoked by Paul's careful use of patriarchal language, the implications for the Corinthians in terms of the collection are obvious: nothing less than their full co-operation and compliance with Paul's wishes would be a satisfactory response to his fatherly advise and instructions.

1 Corinthians 16, 1-4 presents us with the picture of an authoritative apostle who unilaterally takes charge of the organisation of all aspects of the collection, from its conceptualisation to its eventual delivery in Jerusalem. Until the writing of 1 Corinthians, this strategy of Paul apparently delivered the desired results, as his reference to the Galatian collection (1 Cor 16:1) illustrates. But due to the negative reception of 1 Corinthians, their collection drew to an abrupt halt. This serious threat to the success of the collection from the side of the Corinthians, as one of the potentially major contributors to this project, is masterfully handled by Paul in 2 Corinthians 89. As a matter of fact, these chapters reveal Paul at his best "...in terms of religious leadership" (Murphy O'Connor 1996:314).

Paul's basic textual strategy in 2 Corinthians 8-9, which involves the assignment of new roles to the interlocutors, serves to anti-structurally bridge the hierarchical gap between him (as the mild patriarchal figure) and the Corinthians (as his spiritually mature children) within the intra-textual discourse. This pragmatic adjustment of the apostle's own leadership role in order to salvage the collection project in Corinth serves as a warning signal to modern church leaders to take cognizance of: (a) the impact, both positive and negative, of their leadership styles, and (b) the formative role of social institutions and ideologies prevalent in society on their own belief systems and that of their churches. Sensitive leaders are adaptable. They adjust their leadership styles to the situations on hand without compromising their basic beliefs. In this regard, the apostle Paul serves as an excellent role model.

\section{Consulted literature}

Barnett, P 1997. The Second Epistle to the Corinthians (NICNT). Grand Rapids: Eerdmans.

Beckheuer, B 1997. Paulus und Jerusalem. Kollekte und Mission im theologischen Denken des Heidenapostels (EHS T 23). Frankfurt: Peter Lang.

Dixon, S 1987. The sentimental idea of the Roman family, in: Rawson B (ed), Marriage, divorce and children in Ancient Rome, 99-113. Baltimore: John Hopkins University Press. 
-, 1992. The Roman family. Baltimore: John Hopkins University Press.

Holmberg, B 1978. Paul and power. The structure of authority in the primitive church as reflected in the Pauline Writings. Philadelphia: Fortress.

Joubert, S J 1995. Paul as paterfamilias of the Christian household group in Corinth, in: P F Esler (ed), Modelling early Christianity, 213-222. London: Routledge.

Klauck, H J 1986. 2. Korintherbrief (NEB 8). Würzburg: Echter.

-, 1998. Die antike Briefliteratur und das Neue Testament (UTB 2022). Paderborn: Schöningh.

Meeks, W 1983. The first urban Christians. New Haven: Yale University Press.

Murphy-O'Connor, J 1996. Paul- A critical life. Oxford: Claredon.

Orr, W F \& Walther, J A 1976. 1 Corinthians (AncB 32). New York: Doubleday.

Peterman, G W 1997. Paul's gift from Phillipi. Conventions of gift exchange and Christian giving (MSSSNTS 92). Cambridge: University Press.

Saller, R P 1994. Patriarchy, property and death in the Roman family. Cambridge: University Press.

Stevenson, T R 1992. The ideal benefactor and the father analogy in Greek and Roman thought, $C Q$ 42:421-436.

Thiselton, A C 2000. The first epistle to the Corinthians (NIGTC). Grand Rapids: Eerdmans.

Treggiari, S 1991. Roman Marriage: 'Iusti Coniuges' from the Time of Cicero to the Time of Ulpian, Oxford: Oxford University Press.

Van der Watt, J G 2000. Family of the king. Dynamics of metaphor in the Gospel of John. Leiden: Brill.

Wolff, C 1996. Der erste Brief des Paulus an die Korinther (ThHK 7). Berlin: Evangelische Verlagsanstalt. 